\title{
PENERAPAN PENDEKATAN SAINTIFIK MELALUI MODEL PEMBELAJARAN KOOPERATIF TIPE JIGSAW DI KELAS X SMA NEGERI 9 PALU PADA MATERI STOIKIOMETRI
}

\author{
The Implementation of Scientific Approach Through Cooperative-Jigsaw \\ Learning Model in the Class $\mathrm{X}$ at SMA Negeri 9 Palu on the Material \\ Stoichiometry
}

\author{
*Heri Saldi, Siti Nuryanti, dan Jamaludin Sakung \\ Pendidikan Kimia/FKIP - Universitas Tadulako, Palu - Indonesia 94118 \\ Recieved 08 December 2016, Revised 11 January 2017, Accepted 13 February 2017
}

\begin{abstract}
This study aims to determine the influence of implementation a scientific approach through cooperative-jigsaw learning model on Stoichiometry to the learning achievement of students in the class $X$ at SMAN 9 Palu. The method was quasy experiment with pretest-posttest control group design. The population was students of class X SMA Negeri 9 Palu, where the sample was class XB as the experimental group $(n=29)$ and class $X A$ as the control group $(n=27)$, determined by purposive sampling technique. Data were analyzed using nonparametric statistical Mann-Whitney U-Testanalysis. The results showed output "Rank" for mean value of the experimental class was greater than the control class, 33.14 > 23.52. Output of "Test Statistics", Sig. 2-Tailed $(0,026)>0.05$ and Zcount $(-2.23)>$ Ztable (-1.96), as well as each classical completeness and absorption for experimental class were 79\% and $83 \%$, while for the control class were 59\% and 75\%. This study concluded that scientific approach through cooperative-jigsaw model on Stoichiometry influenced positive to the learning achievement of students in the class X at SMA Negeri 9 Palu.
\end{abstract}

Keywords: scientific approach, jigsaw type, learning achievement of chemistry, stoichiometry

\section{Pendahuluan}

Proses pembelajaran adalah proses interaksi siswa dengan guru dan sumber belajar pada suatu lingkungan belajar. Sistem pendidikan di Indonesia masih menerapkan paradigm lama yaitu proses pembelajaran berjalan satu arah saja dan didominasi oleh guru. Kesalahan guru dalam memilih strategi pembelajaran dapat menyebabkan siswa kurang tertarik pada pembelajaran sehingga berdampak pada berkurangnya motivasi dan keaktifan siswa selama proses belajar-mengajar. Hal tersebut juga akan menyebabkan hasil belajar siswa yang tidak maksimal (Hertiavi, dkk., 2010).

Chu (2014), menyatakan bahwa metode pembelajaran kooperatif terbukti menguntungkan dan berdampak positif terhadap hasil kognitif dan afektif serta prestasi akademik siswa. Pembelajaran kooperatif adalah salah satu bentuk model pembelajaran

\section{*Correspondence:}

Heri Saldi

Program Studi Pendidikan Kimia, Fakultas Keguruan dan Ilmu Pendidikan, Universitas Tadulako

email: saldiheri76@gmail.com

Published by Universitas Tadulako 2017 yang berdasarkan paham konstruktivisme. Pembelajaran koopeatif merupakan strategi belajar dengan sejumlah siswa sebagai anggota kelompok kecil yang tingkat kemampuannya berbeda. Penyelesaian tugas kelompok menuntut siswa harus saling bekerja sama, saling membantu untuk memahami materi pelajaran (Suparmi, 2012).

Seiring dengan berkembangnya ilmu pengetahuan dan teknologi, seharusnya pola mengajar guru terhadap siswa juga hendaknya bervariasi, tidak hanya monoton (berjalan satu arah), yaitu guru menjelaskan dan murid duduk dan mendengarkan. Salah satu model pembelajaran yang dapat mengakomodasi interaksi antar siswa serta interaksi siswa dan guru adalah model pembelajaran kooperatif. Salah satu tipe model kooperatif adalah tipe jigsaw. Salah satu metode pengajaran alternatif untuk mengajar adalah model kooperatif tipe jigsaw, dimana model ini telah diklaim dapat meminimalkan daya saing siswa salam belajar dan mendorong siswa untuk bekerja bersamasama (Tran, 2012). 
Mengduo \& Xiaoling (2010), mengemukakan bahwa model kooperatif tipe jigsaw dapat mengurangi keengganan siswa untuk berpartisipasi dalam proses pembelajaran dan membantu menciptakan keaktifan siswa di dalam kelas. Penggunaan model pembelajaran ini secara efektif dan efisien akan meningkatkan peran aktif siswa pada proses pembelajaran dan kebosanan siswa dalam menerima pelajaran akan berkurang (Budiawan \& Arsani, 2013).

Model kooperatif tipe jigsaw memberikan kesempatan pada siswa untuk melakukan semacam sharing antar kelompok dengan cara membentuk kelompok ahli. Model jigsaw ini bukan saja menjadikan pembelajaran kimia berlangsung secara dinamis tetapi juga menarik karena adanya variasi kelompok asal dan kelompok ahli, bila dalam pembelajaran kimia dengan metode ceramah, siswa memperoleh pengetahuan hanya melalui guru, maka melalui penerapan cooperative learning tipe jigsaw setiap siswa dapat memperoleh pengetahuan dari 4 (empat) sumber sekaligus secara bersamaan, yaitu bersumber dari siswa itu sendiri secara pribadi, siswa lain di dalam kelompok, kelompok lain melalui kelompok atau tim ahli, dan guru sebagai fasilitator pembelajaran (Aswirna, 2012).

Pendekatan saintifik dalam proses ilmiah merupakan suatu cara untuk mempelajari aspekaspek tertentu dari alam secara terorganisir dan sistematik. Pendekatan saintifik menuntut siswa harus dapat menggunakan metode-metode ilmiah yaitu menggali pengetahuan melalui mengamati, mengklasifikasi, memprediksi, merancang, melaksanakan eksperimen dan mengkomunikasikan pengetahuannya kepada orang lain dengan menggunakan keterampilan berfikir, dan menggunakan sikap ilmiah seperti ingin tahu, hati-hati, objektif, dan jujur (Marjan, dkk., 2014).

Pendekatan saintifik adalah pendekatan yang sistematik untuk memperoleh suatu kesimpulan ilmiah. Pendekatan saintifik juga sering disebut pendekatan induktif karena dalam prosesnya, pendekatan saintifik dimulai dari hal-hal yang bersifat spesifik ke kesimpulan yang bersifat general (Sujarwanta, 2012).

Berdasarkan hasil wawancara peneliti dengan salah satu guru mata pelajaran kimia di SMA Negeri 9 Palu, disebutkan bahwa metode pembelajaran yang sering diterapkan yaitu ceramah dan beberapa kali menggunakan model kooperatif namun belum efektif dan tidak terkelola secara baik. Adapun prestasi rata-rata siswa baik di kelas X IPA 1 (sekarang kelas A) maupun kelas X IPA 2 (Sekarang kelas
B) pada semester awal yaitu mencapai angka 78 . Angka tersebut memang sudah dalam kriteria tuntas, namun masih terbilang rendah, dimana kriteria ketuntasan minimal (KKM) mata pelajaran kimia yaitu 76. Peneliti tertarik untuk mengetahui pengaruh penerapan pendekatan saintifik melalui model pembelajaran kooperatif tipe jigsaw dengan pendekatan saintifik melalui model pembelajaran individual pada materi stoikiometri terhadap hasil belajar siswa kelas $\mathrm{X}$ di SMA Negeri 9 Palu. Materi yang di ajarkan adalah stoikiometri karena materi ini sesuai dengan karaktristik pembelajaran kooperatif, yaitu struktur materinya bersifat horizontal sehingga dapat dibagi-bagi dalam beberapa kelompok (Alamsyah, 2015).

Sianus, dkk. (2010), mengemukakan bahwa pembelajaran kooperatif tipe jigsaw membuat siswa akan termotivasi dan merasa bertanggungjawab atas materi yang telah dipelajari karena siswa yang bersangkutan harus menyampaikannya kepada temannya yang lain. Siswa bekerja dengan sesama siswa dalam suasana gotong royong dan mempunyai banyak kesempatan untuk mengelola informasi dan meningkatkan ketrampilan berkomunikasi, serta menjalin interaksi yang menyeluruh (Sugianto, dkk., 2014).

\section{Metode}

Penelitian ini merupakan penelitian eksperimen semu (Quasi eksperiment), bertujuan untuk menentukan pengaruh penerapan pendekatan saintifik melalui model pembelajaran tipe jigsaw terhadap hasil belajar siswa kelas X SMA Negeri 9 Palu. Secara garis besar penelitian ini dilaksanakan dalam tiga tahap yaitu tahap persiapan, tahap pelaksanaan, dan tahap akhir. Adapun tahap-tahap tersebut adalah sebagai berikut :

Tahap Persiapan : Observasi lokasi penelitian, menentukan populasi dan sampel penelitian, dan menyusun instrumen tes, skenario pembelajaran yang akan digunakan dalam penelitian untuk kelas eksperimen dan kelas kontrol.

Tahap Pelaksanaan : Pemberian tugas awal sebelum melakukan perlakuan atau proses belajar (pretest), pemberian perlakuan (penyajian materi). Kelas X B yang dijadikan kelas eksperimen diberikan perlakuan dengan menerapkan pendekatan saintifik melalui model pembelajaran kooperatif tipe jigsaw dan kelas X A sebagai kelas kontrol menerapkan pendekatan saintifik melalui model pembelajaran individual, dan pemberian tes evaluasi pada kelas eksperimen dan kelas 
kontrol untuk memperoleh data hasil belajar siswa (Posttest).

Tahap Akhir: Kegiatan yang dilakukan pada tahap ini adalah pengumpulan, pengolahan dan analisis data serta pelaporan hasil penelitian. (Barizi \& Nasetion, 1997).

Pelaksanaan penelitian pada semester genap tahun pelajaran 2014/2015, mulai bulan April sampai bulan Mei tahun 2015. Populasi dalam penelitian ini adalah semua siswa kelas $\mathrm{X}$ di SMA Negeri 9 Palu yang terdaftar pada tahun ajaran 2014/2015 sebanyak 5 kelas dengan jumlah 144 siswa.

Teknik pengambilan sampel dengan cara purposive sampling dengan melihat kelas yang mempunyai hasil belajar siswa relatif sama dan berdasarkan kelas peminatan (IPA) pada saat kurikulum 2013 masih berlaku, berdasarkan hasil wawancara dengan guru bidang studi kimia dan berhubung jumlah kelas yang dahulunya adalah jurusan IPA sebelum kurikulum 2013 dihentikan dan kembali menggunakan KTSP di SMA Negeri 9 Palu hanya berjumlah 2 kelas. Sampel dalam penelitian ini terdiri dari 2 kelas yaitu kelas X B sebagai kelas Eksperimen dan kelas X A sebagai kelas kontrol, dengan jumlah siswa pada kelas X B yaitu 29 siswa dan kelas X A yaitu 27 siswa.

Instrumen dalam penelitian ini terdiri dari rencana pelaksanaan pembelajaran (RPP) dan tes hasil belajar berbentuk pilihan ganda yang berjumlah 21 butir soal, setelah dilakukan uji validitas dan reliabilitas tes yang berjumlah 40 butir soal.

Teknik analisis data yang digunakan dalam penelitian ini dengan menggunakan metode analisis statistika deskriptif dan statistika inferensial. Teknik analisis statistika deskriptif dipakai untuk menggambarkan pencapaian masing-masing variabel sedangkan analisis statistika inferensial menggunakan metode statistik nonparametrik untuk menguji hipotesis yang akan menentukan kita dalam menarik kesimpulan terhadap penerapan pendekatan saintifik melalui model pembelajaran kooperatif tipe jigsaw (Djarwanto, 1997).

Perhitungan n-gain bertujuan untuk mengetahui besar peningkatan hasil belajar siswa pada kelas eksperimen dan kelas kontrol. Pengujian kebenaran hipotesis ini dilakukan dengan menggunakan uji Mann-Whitney. Uji Mann-Whitney adalah uji nonparametrik yang menjadi alternatif dari uji t (Uji parametrik). Kelebihan uji ini dibandingkan uji t adalah uji ini dapat digunakan pada data peringkat. Uji Mann-Whitney disebut juga sebagai uji U, karena statistik yang digunakan untuk menguji hipotesis nolnya disebut U (Harinaldi, 2005).

\section{Hasil dan Pembahasan}

\section{Tes Kemampuan Awal Siswa (Pretest)}

Pretest bertujuan untuk mengetahui kemampuan awal siswa kelas eksperimen dan kelas kontrol sebelum pembelajaran materi stoikiometri dilaksanakan. Hasil pretest hasil belajar siswa, diperoleh rata-rata nilai kelas eksperimen adalah 23,59 dan kelas kontrol adalah 25,07, seperti terlihat dalam Tabel 1 .

Tabel 1. Analisis Data Pretest Hasil Belajar

\begin{tabular}{|c|c|c|}
\hline \multicolumn{3}{|c|}{ Siswa } \\
\hline \multirow{2}{*}{ Uraian } & \multicolumn{2}{|c|}{ Tes Awal ( Pretest) } \\
\hline & Kelas eksperimen (X B) & Kelas kontrol (X A) \\
\hline Sampel & 29 & 27 \\
\hline Nilai terendah & 0 & 0 \\
\hline Nilai tertinggi & 38 & 43 \\
\hline Nilai rata-rata & 23,59 & 25,07 \\
\hline Standar deviasi & 9,73 & 9,62 \\
\hline
\end{tabular}

Hasil tersebut menunjukkan bahwa ratarata nilai pretest hasil belajar siswa kelas eksperimen lebih rendah dari rata-rata nilai pretest hasil belajar siswa kelas kontrol namun perbedaannya tidak terlalu signifikan.

\section{Tes Kemampuan Akhir Siswa (Posttest)}

Deskripsi hasil analisis data posttest hasil belajar siswa disajikan dalam Tabel 2 berikut ini.

Tabel 2. Analisis Data Posttest Hasil Belajar

\begin{tabular}{|c|c|c|}
\hline \multicolumn{3}{|c|}{ Siswa } \\
\hline \multirow{2}{*}{ Uraian } & \multicolumn{2}{|c|}{ Tes Akhir (Posttest) } \\
\hline & Kelas eksperimen (X B) & Kelas kontrol (X A) \\
\hline Sampel & 29 & 27 \\
\hline Nilai terendah & 57 & 48 \\
\hline Nilai tertinggi & 95 & 95 \\
\hline Nilai rata-rata & 82,62 & 74,67 \\
\hline Standar deviasi & 12,40 & 12,29 \\
\hline
\end{tabular}

Hasil tersebut menunjukkan bahwa rata-rata nilai posttest hasil belajar siswa kelas eksperimen lebih tinggi daripada rata-rata nilai posttest hasil belajar siswa kelas kontrol. Sedangkan ketuntasan klasikal kelas eksperimen lebih tinggi dibanding kelas kontrol. Berdasarkan hasil tersebut, maka rata-rata nilai posttest hasil belajar serta ketuntasan klasikal siswa kelas eksperimen yang diajarkan dengan pendekatan 
saintifik melalui model pembelajaran kooperatif tipe jigsaw lebih tinggi dibanding rata-rata nilai posttest hasil belajar siswa kelas kontrol yang diajar dengan pendekatan saintifik model pembelajaran individual.

\section{Perhitungan N-Gain}

Perhitungan indeks gain dilakukan sebagai uji pendukung untuk menentukan besar peningkatan hasil belajar kelas eksperimen dan kontrol yang dapat dilihat pada Gambar 1.

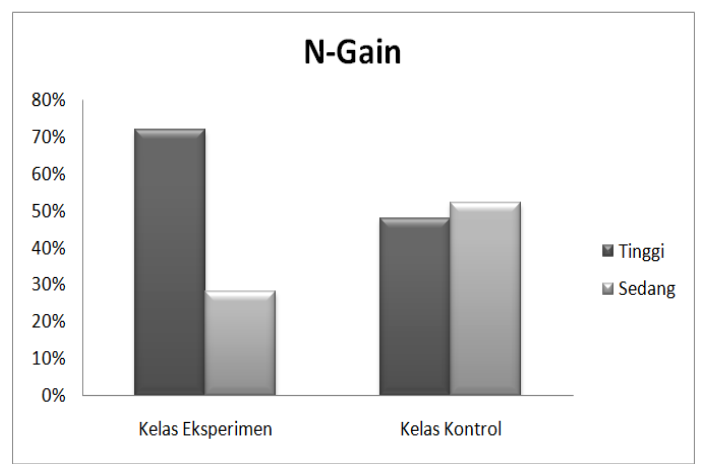

Gambar 1. Hasil Perhitungan N-Gain Kelas Eksperimen dan Kontrol

\section{Pengujian Hipotesis}

Pengujian hipotesis penelitian ini menggunakan uji non parametrik analisis Mann-Whitney U-Test, uji ini dilakukan karena berdasarkan perhitungan, diperoleh sampel dalam penelitian ini tidak berdistribusi normal. Uji ini juga didukung oleh referensi yang dikemukakan oleh Djarwanto (1997) bahwa apabila sampel kecil (n1 atau n2 $\leq 40)$, maka dapat digunakan uji Mann-Whitney. Perhitungan analisis data yaitu dengan bantuan perhitungan program SPSS 20 terhadap data hasil belajar siswa. Hasil dari analisis MannWhitney U-Test akan memenuhi kriteria pengujian hipotesis $\mathrm{H}_{1}$ diterima dan $\mathrm{H}_{0}$ ditolak jika, Uhitung lebih kecil dari Utabel, untuk sampel berjumlah $\leq 20$. Penelitian ini, sampel berjumlah 29 orang (Kelas Eksperimen) dan 27 orang (kelas kontrol) maka pengujian hipotesisnya menggunakan pendekatan tabel Z. Adapun hipotesis yang diajukan dalam penelitian ini adalah pendekatan saintifik melalui model pembelajaran tipe jigsaw berpengaruh positif terhadap hasil belajar siswa pada mata pelajaran kimia di kelas X SMA Negeri 9 Palu.

Hasil analisis pengujian, untuk variabel hasil belajar yaitu Zhitung $\square$ Ztabel yaitu $-2,23<-1,96$ dan P.Sig $\square$ alpha yaitu 0,026 $<0,05$. Berdasarkan hasil tersebut maka dapat disimpulkan bahwa hipotesis yang diajukan adalah menolak $\mathrm{H}_{0}$ dan menerima $\mathrm{H}_{1}$, yaitu pendekatan saintifik melalui model pembelajaran kooperatif tipe jigsaw berpengaruh positif terhadap hasil belajar siswa pada mata pelajaran kimia di kelas X SMA Negeri 9 Palu.

Hasil analisis data pretest hasil belajar siswa kelas eksperimen dengan menerapkan pendekatan saintifik melalui model pembelajaran kooperatif tipe jigsaw dan kelas kontrol yang diajar dengan menerapkan pendekatan saintifik model pembelajaran individual, diperoleh rata-rata nilai kelas eksperimen adalah 23,59 dan kelas kontrol adalah 25,07. Berdasarkan hasil tersebut, bahwa rata-rata nilai pretest hasil belajar kelas eksperimen lebih rendah dari pada rata-rata nilai pretest hasil belajar kelas kontrol, namun tidak terdapat perbedaan yang signifikan, sehingga dapat disimpulkan bahwa kemampuan awal siswa kelas eksperimen dan kelas kontrol relatif sama pada materi stoikiometri.

Pembelajaran di kelas eksperimen diterapkan pendekatan saintifik melalui model pembelajaran kooperatif tipe jigsaw yaitu model pembelajaran dimana terdapat kelompok asal dan kelompok ahli dengan menggunakan prinsip pendekatan saintifik yang bersifat sosial, dimana siswa dituntun untuk belajar bekerjasama dalam menyelesaikan suatu masalah, sedangkan pada kelas kontrol menggunakan prinsip pendekatan saintifik yang bersifat individual.

Tujuan penerapan pembelajaran kooperatif tipe jigsaw adalah agar siswa lebih mampu bekerjasama dengan siswa lain, mampu mengungkapkan ide dan gagasan mereka dengan baik, menjadi lebih aktif serta meningkatkan keberanian dan kepercayaan diri siswa dalam hal yang positif. Hal ini sejalan dengan pendapat yang dikemukakan oleh Prawoto (2012), pengajaran yang efektif menghendaki guru memfasilitasi siswa belajar dengan metode diskusi agar siswa bisa belajar kerja sama dan bisa belajar aktif untuk melatih keberanian dan kepercayaan diri siswa dalam kegiatan belajar mengajar di kelas.

Kelas kontrol, dengan proses pembelajaran dilakukan dengan menggunakan pembelajaran individual. Pelaksanaan proses pembelajaran pada kelas kontrol, pertama-tama yaitu guru menyampaikan materi kepada siswa (proses mengamati), kemudian guru memberikan kesempatan kepada siswa untuk menanyakan apabila yang belum dipahami (proses menanyakan). Selanjutnya guru menunjuk 
salah satu siswa untuk menjawab temannya atau mempersentasekan kreativitas berpikir siswa mengenai pengetahuan yang telah diperoleh atas pertanyaan temannya (proses mempersentasekan). Guru dalam hal ini bertindak menyempurnakan jawaban siswa (proses mengumpulkan data). Tahap terakhir pada proses pembelajaran ini, guru bersamasama dengan siswa menyimpulkan materi yang telah dipelajari (proses menyimpulkan). Setelah itu, guru memberikan tugas individu berbentuk tertulis (essay test) untuk mengukur tingkat keberhasilan yang dicapai oleh siswa pada tiap pertemuan.

Nilai posttest hasil belajar siswa aspek kognitif diperoleh dari jawaban benar soal pilihan ganda mengenai materi stoikiometri. Hasil analisis nilai posttest siswa diketahui bahwa rata-rata nilai hasil belajar kelas eksperimen sebesar 82,62 dan kelas kontrol sebesar 74,67. Data nilai posttest kemudian dianalisis dengan menggunakan uji Mann-Whitney U-Test. Berdasarkan uji Mann-Whitney U-Test (terlampir), diperoleh nilai dengan hasil analisis posttest hasil belajar diperoleh output "Rank" untuk nilai mean kelas eksperimen lebih besar dari kelas kontrol yaitu 33,14 $\square 23,52$. Output "Test Statistic", P.Sig $(0,026) \square 0,05$ dan $Z$ hitung $(-2,23) \square$ $\mathrm{Z}$ table $(-1,96)$, sehingga dapat disimpulkan bahwa nilai posttest hasil belajar siswa kelas eksperimen lebih baik dari pada kelas kontrol. $\mathrm{Hal}$ ini sejalan dengan hasil penelitian Azizah (2013), yang menyatakan bahwa nilai posttes kelas eksperimen (menggunakan model pembelajaran kooperatif tipe jigsaw lebih baik daripada kelas kontrol (menggunakan model pembelajaran konvensional).

Hasil belajar siswa kelas eksperimen lebih baik dari pada kelas kontrol karena adanya pengaruh penerapan pendekatan saintifik melalui model pembelajaran kooperatif tipe jigsaw. Dimana proses pendekatan saintifik yang terjadi pada kelas eksperimen lebih banyak, sehingga daya serap siswa terhadap pelajaran dapat lebih terasah dibanding pendekatan saintifik yang terjadi pada kelas kontrol. Tingkat daya serap siswa pada materi stoikiometri dengan menerapkan pendekatan saintifik lebih baik dibandingkan dengan pembelajaran konvensional sesuai dengan Machin (2014), menyatakan bahwa implementasi pendekatan saintifik, berpengaruh positif terhadap ha $\neg$ sil belajar kognitif, afektif dan psikomotorik seluruh siswa yang mengikuti pembelajaran. Pendapat tersebut didukung oleh Hidayat (2014), yang menyatakan bahwa penerapan pendekatan saintifik meningkatkan prestasi belajar siswa.

Model pembelajaran juga sangat berpengaruh terhadap hasil belajar siswa, terbukti hasil belajar dengan menerapkan model kooperatif tipe jigsaw pada kelas eksperimen lebih baik dibandingkan model pembelajaran individual pada kelas kontrol. Hal ini sesuai dengan Sianus, dkk (2010) menyatakan bahwa penerapan model pembelajaran tipe jigsaw dapat meningkatkan aktivitas belajar siswa. Pendapat tersebut di dukung oleh Aswirna (2012), menyatakan bahwa penerapan model pembelajaran kooperatif tipe jigsaw dapat meningkatkan prestasi belajar siswa.

Uji pendukung, disertakan pula perhitungan indeks gain yang bertujuan untuk mengetahui besarnya peningkatan hasil belajar siswa di kelas eksperimen dan kelas kontrol. Berdasarkan perhitungan rata-rata indeks gain data nilai hasil belajar siswa dari jumlah siswa sebanyak 29 orang kelas eksperimen dan 27 orang kelas kontrol, diperoleh indeks gain kriteria tinggi di kelas eksperimen sebesar $72 \%$ dan kelas kontrol sebesar $48 \%$, kriteria sedang di kelas eksperimen sebesar $28 \%$ dan kontrol $52 \%$ sedangkan kriteria rendah di kelas eksperimen dan kontrol sebesar 0\%. Jadi dapat disimpulkan bahwa indeks gain nilai hasil belajar kelas eksperimen lebih tinggi peningkatannya dari pada kelas kontrol.

Model pembelajaran kooperatif tipe jigsaw merupakan salah satu model kooperatif yang cocok diterapkan pada pembelajaran kimia, seperti pada materi stoikiometri. Materi ini sesuai dengan karaktristik pembelajaran kooperatif, yaitu struktur materinya bersifat horizontal sehingga dapat dibagi-bagi dalam beberapa kelompok.

Stoikiometri yang identik dengan perhitungan lebih baik dikerjakan dengan cara kerjasama antar siswa, untuk mempermudah proses analisis masalah yang terdapat dalam materi tersebut. Materi yang banyak menggunakan rumus sangat sukar dan lebih lambat, jika hanya ditelaah oleh masing-masing siswa secara individual. Sehingga mempengaruhi hasil belajar siswa. Berdasarkan hasil penelitian disimpulkan bahwa model pembelajaran kooperatif tipe jigsaw berpengaruh positif terhadap hasil belajar siswa.

\section{Kesimpulan}

Berdasarkan hasil analisa data, diperoleh analisis hasil belajar siswa yaitu P. Sig $(0,026)$ 
$>0,05$ dan $Z$ hitung $(-2,23)>Z$ table $(-1,96)$, serta ketuntasan klasikal dan daya serap klasikal masing-masing yaitu kelas eksperimen adalah $79 \%$ dan $83 \%$ sedangkan kelas kontrol adalah 59\% dan 75\%. Berdasarkan hasil pengujian hipotesis tersebut, maka $\mathrm{H}_{0}$ ditolak dan $\mathrm{H}_{1}$ diterima sehingga dapat disimpulkan bahwa pendekatan saintifik melalui model kooperatif tipe jigsaw pada materi stoikiometri berpengaruh positif terhadap hasil belajar siswa kelas X di SMA Negeri 9 Palu.

\section{Ucapan Terima Kasih}

Penulis mengucapkan terimakasih kepada Irsan selaku Kepala sekolah SMA Negeri 9 Palu, Alamsyah selaku Guru Kimia di SMA Negeri 9 Palu dan siswa kelas X.A dan X.B SMA Negeri 9 Palu.

\section{Referensi}

Alamsyah. (2015). Guru mata pelajaran kimia. SMA Negeri 9 Palu.

Aswirna, P. (2012). Peningkatan prestasi belajar siswa dalam pembelajaran kimia dengan penerapan cooperative learning model jigsaw pada kelas X IPA3 di SMA Negeri 1 Padang. Jurnal Al-Tálim, 19(2), 158-165.

Azizah, N. (2013). Pengaruh metode pembelajaran jigsaw terhadap hasil belajar mata pelajaran dasar kompetensi kejuruan di SMK Wongsorejo Gombong. Jurnal Penelitian, 1(1), 1-12.

Barizi \& Nasetion, A. (1997). Metode statistika untuk penarikan kesimpulan. Jakarta: PT. Gramedia.

Budiawan, M., \& Arsani, A. (2013). Pengaruh model pembelajaran kooperatif tipe jigsaw dan motivasi belajar terhadap prestasi belajar ilmu fisiologi olahraga. Jurnal Pendidikan Indonesia, 2(1), 138-144.

Chu, S.-Y. (2014). Application of the jigsaw cooperative learning method in economics course. International Journal of Managerial Studies and Research (IJMSR), 2(10), 166172.

Djarwanto. (1997). Statistik nonparametrik. Yogyakarta: BPFE Yogyakarta.

Harinaldi. (2005). Prinsip-prinsip statistik untuk teknik dan sains. Jakarta: Erlangga.

Hertiavi, M. A., Langlang, H., \& Khanafiyah, S. (2010). Penerapan model pembelajaran kooperatif tipe jigsaw untuk peningkatan kemampuan pemecahan masalah siswa SMP. Pendidikan Fisika Indonesia, 6(1). 5357.

Hidayat, A. (2014). Penerapan pendekatan saintifik pada mata pelajaran pendidikan agama islam untuk peningkatan prestasi belajar kelas 1 B SDN 1 Bantul tahun ajaran 2013-2014. Yogyakarta: Universitas islam negeri Sunan Kalijaga.

Machin, A. (2014). Implementasi pendekatan saintifik, penanaman karakter dan konservasi pada pembelajaran materi pertumbuhan SMA Negeri 1 Dempet, Demak. Jurnal Pendidikan IPA Indonesia, 3(1), 28-35.

Marjan, J., Arnyana, P., \& Setiawan, N. (2014). Pengaruh pembelajaran pendekatan saintifik terhadap hasil belajar biologi dan keterampilan proses siswa MA Mu'Allimat NW Pancor Selong Kabupaten Lombok Timur Nusa Tenggara barat. E-Jurnal Pascasarjana Universitas Pendidikan Ganesha, 4(1). 1-12.

Mengduo, Q \& Xiaoling, J. (2010). Jigsaw strategy as a cooperative learning technique: focusing on the language learners. Chinese Journal of Applied Linguistics (Bimonthly), 33(4), 113-125.

Prawoto, A. (2012). Pembelajaran dengan pendekatan based brain learning untuk meningkatkan hasil belajar matematika. Bandung: Pascasarjana UPI.

Sianus, S., Syukri, \& Marzuki. (2010). Penerapan model pembelajaran jigsaw pada ilmu pengetahuan social untuk meningkatkan aktivitas belajar peserta didik. Jurnal PGSD FKIP Universitas Tanjungpura Pontianak. 1(1), 1-15.

Sugianto, Armanto, D \& Harahap, M. B. (2014). Perbedaan penerapan model pembelajaran kooperatif tipe jigsaw dan stad ditinjau dari kemampuan penalaran dan komunikasi matematis siswa SMA. Jurnal Dikdaktik Matematika. 1(1), 114-128. 
Sujarwanta, A. (2012). Mengkondisikan pembelajaran IPA dengan pendekatan saintifik. Jurnal Nuansa pendidikan, 16(1), 75-78.

Suparmi. (2012). Pembelajaran kooperatif dalam pendidikan multikultural. Jurnal
Pembangunan Pendidikan, 1(1), 108-118.

Tran, V. D. (2012). The effects of jigsaw learning on students' attitudes in a vietnamese. higher education classroom. International Journal of Higher Education, 1(2), 9-20. 